\title{
Migration of Javanese Language and its Influence on Sundanese Language Pangandaran Dialect in West Java, Indonesia: A Studi in Geolinguistic
}

\author{
Wagiati $^{1}$, Nani Darmayanti ${ }^{2 *}$, Duddy Zein ${ }^{3}$ \\ ${ }^{1,2}$ Faculty of Cultural Sciences, Universitas Padjadjaran, Bandung - Sumedang KM 21, Jatinangor, Sumedang, \\ Indonesia \\ ${ }^{3}$ Faculty of Communication Sciences, Universitas Padjadjaran, Bandung - Sumedang KM 21, Jatinangor, \\ Sumedang, Indonesia
}

*Corresponding Author: Nani Darmayanti, Faculty of Cultural Sciences, Universitas Padjadjaran, Bandung - Sumedang KM 21, Jatinangor, Sumedang, Indonesia

\begin{abstract}
This research examines the migration of Javanese language and its influence on Sundanese language Pangandaran dialect, in West Java Province, Indonesia, which with the study is geolinguistic. The approaches used in this research are theoretical approach and methodological approach. Theoritically, the approach used in this research is the diactology research. As for methodology, the method used in this research is the qualitative-descriptive method. This study starts with provision data done through the conversation (cakap) and observation (simak) method. The data is the language in system of existing kinship, the pronouns, and the body parts which is collected by using the vocabulary basic list method (Swadesh list). The data is analyzed by using the comparative-synchronic method. This research was carried out in Pangandaran Regency, by selecting five districts as observation area which determined based on the direction of the wind. The districts are Cimerak District, Sidamulih District, Kalipuncang District, Padaherang District, and Pangandaran District. The research results show that (1) there is traces of language migration and the influence of Javanese language in Pangandaran, West Java, Indonesia, which can be seen from the existence of the same glosses and etymons; (2) pattern of Javanese language migration through the wave theory with centrifugal pattern (away from the unity and standardization); (3) the determinants of Javanese language migration are historical factors, geographical-demographic factors, and political factors.
\end{abstract}

Keywords: language migration, dialect, geolinguistic

\section{INTRODUCTION}

Language political policy, which in this case is the inauguration of Indonesian language as the national language, is a thing should be grateful. As the national language, Indonesian language has succeeded in becoming an instrument of communication and interaction between the tribes living in Indonesia. The differences of sociocultural and lingual is no longer a barrier to communication between communities. With the existence of Indonesian language as the national language, communication between tribes is easy to do. Several possibilities may occur if Indonesian language is not chosen as a national language. First, residents in areas with different languages will communicate in their own ways by using their own languages and they do not understand each other. This situation certainly doesn't show effective communication in practice, even potentially leads to misperception and miscommunication, or can be called "confusion communication". Confusion communication will later be vulnerable to creating horizontal conflicts. If this condition continues, there will never be a social agreement which makes Indonesia as a unitary nation. Second, it raises a social consensus to choose and take one od the wealth of 413 regional languages (Pusat Bahasa, 2009 in Wahyuni, 2010) as a national language. However, this second condition will present two major risks, namely the emerge of jealousy towards regions whose languages are chosen as national languages, and the potential for the emergence of ethnocentric attitudes towards the language-speaking tribes chosen as national languages. Based on abovementioned factors, the selection of Indonesian language as a national language can be said to be an appropriate policy in the midst of the multicultural conditions of Indonesia. 
Political policy of Indonesian language as a national language still raises a dilemma. On the one hand, the policy is positive because it has been able to reduce the potential for disintegration between tribes to happen in Indonesia. However, on the other hand, the political policy which places Indonesian language as the national language, has at least influenced the use of local language. That is why, the existence of local languages begins currently to experience functional pressure, along with the politics of the language. Based on the facts mentioned above, the local language today is now being abandoned by their native speakers, for they prefer talk in Indonesian language to their own local language. Thus, consciously or not, the local languages have experienced language shifts. If this condition stays, it may lead the local languages to the death (language death). This is in line with Mbete (2003: 14-15) who states that if in a family, the practice of speaking between parents and their children -and vice versa- is rarely done or even is not done by using local language, this condition is a serious sign of the death language.

This condition is increasingly alarming when it is associated with social reality that shows the symptoms of globalization which places English as an international language. Internationalization of English also has a little influence on the lingual dynamics that exist in social life in the midst of society. It is not excessive, if this situation is feared it will lead to the marginalization of local languages by the speakers themselves. People are increasingly abandoning their regional languages as the first language. Wijana (2006) states that so far there has not been sufficient evidence to explain that learning two languages or more will cause interference. According to him, bilingual or multilingual people will be accustomed to seeing things with different or even conflicting points of view. Thus, when compared to monolingual people, bilingual or multilingual people will be more tolerant of the differences.

In the midst of the dynamics of mutual influence between languages, and the growing concern about the extinction of local languages, instincts towards language preservation have been naturally owned by speakers of the language since long ago. Tensile vocabulary and mutual influence between languages is a real form of language retention efforts. Unconsciously, the vocabulary tug has an influence on the language of the opponent and the language of the speakers themselves. These influences can be adapted directly without going through adjustments and sound changes or vice versa. Thus, the existence of mutual influence is a form of resistance from each language that intersects each other.

This condition is found in the Sundanese language dialect in Pangandaran, West Java, Indonesia, which has connection with Javanese language. Both of the languages influence each other so that the glosses found have the same realization and etymon. This condition, in the future, create the confusion about the status of language in the region where the both languages meet. This confusion will be seen clearly when dialectometric calculations are carried out to determine the status of languages and dialects in the region. Until now, indeed, the boundary of language and dialect is still becoming issues of prolonged debate among fellow dialectologists. This is since determining the right and accurate criteria to distinguish between language and dialect is one of the complicated theoretical issues in the linguistic studies.

Pangandaran is one of the districts in West Java Province with a high level of population complexity. One of the complexities is caused by the geographical location of Pangandaran which borders on Cilacap Regency, Central Java Province. This condition makes Pangandaran as one of the language enclave areas in which it allows the intersection of two or more languages. Intersection between languages will create complex lingual dynamics. Pangandaran Regency has most Sundanese people. However, because one of the political policies of the New Order, namely transmigration and equal distribution of the population in the territory of Indonesia, especially Java, made many Javanese residents who also lived and settled in Pangandaran. This transmigration also influenced the sociocultural and lingual dynamics in Pangandaran.

Sundanese and Javanese language, in linguistic status, are two related languages, which classified as the Austronesian family or Nusantara (Mulyana, 1975). The relation between peer languages turns out not to be as close as one language to another, some are closer or farther away (Blust, 1977). Blust classifies allied languages based on the proximity of the relationship called subgrouping. There have been many studies on language subgrouping in Indonesia, such as Dyen's (1965), Mees (1967), Blust 
(1977), or Suryata (1998). Suryata (1998) specifically, classifies Sundanese and Javanese language as a kinship language that has a fairly close relationship.

This research aims to uncover the relations of closeness between Sundanese and Javanese language which experienced contact in Pangandaran Regency. Language relations can be seen from the existence of mutual influence between the two with certain lingual patterns and certain levels of defense. On the other hand, this research also aims to reveal the pattern of Javanese language migration that is spread in Pangandaran Regency, West Java Province, Indonesia. Language migration theory says that a language can migrate from one place to another with certain patterns. The language migration can occur along with the speaker and may not be with the speaker.

The results of this study are useful for the development of linguistic theory, especially dialectology and comparative linguistics, and practically provide input for policy making in the context of language retention and language development, especially in Pangandaran Regency and generally in West Java Province.

\section{METHOD}

There are two approach used in this study, namely the theoretical approach and the methodological approach. Theoretically, the approach used in this study is the dialectology approach. Weijnen et al. (Ayatrohaedi, 2002: 1-2) argues that dialect is a linguistic system that is used by one community to distinguish them from other neighboring communities that use different systems despite their close relationship. Mahsun (1995) limits dialect as a variety of languages used in some countries (regional dialects), or by residents who have certain social classes (social dialects or sociolect), which differ in several words, grammar, and / or pronunciation from other forms in the same language. From some of the views above, it can be concluded that the dialect is a system of language variations.

As for methodologically, this study uses qualitative-descriptive methods. Qualitatively, it means the data examined and the results of the analysis are obtained from recordings, observations, interviews, or written material and the data is described in words or letters not numbers (Djojosuroto and Kinayati, 2004: 17). Meanwhile, the descriptive approach is based on facts, which are empirically available to the speakers, so the results are in the description of language as it is. The use of this descriptive method is in line with what Sudaryanto (2015) explained that the data obtained is the result of observations of the author without assessing the correct or incorrect data.

This research was conducted in three stages, which are (1) provision of the data, (2) data analysis, and (3) presenting the research result.

The research begins with the provision of data which with the methods used are conversation (cakap) and observation (simak) method (Sudaryanto, 2015). At the stage of providing data, the first step taken is to determine the area that is used as the location of the research. After that, the steps that must be carried out are to provide data using the skillful method, namely the method of collecting lingual data by conducting a conversation between researchers and speakers as resource persons. The data collection is also done by several techniques, including doing directed conversation, asking direct questions, asking indirect questions, provoking answers, and asking for multiple answers.

The instrument used in the collecting data process is a list of vocabulary (swadesh) which contains several parts that will be asked, namely the language in the existing kinship system, pronouns, and body parts. The following are data collection tools (instruments) used in the form of:

a) Data informants addressed to informants to reveal the identity of informants, starting from the place of birth, length of stay in the research area, and mobility of the informant;

b) Village data that is addressed to the village head and the population;

c) Questions list which contains vocabulary lists addressed to informants to reveal vocabulary data.

Furthermore, in the observation method, the researcher directly interviews the informants (Teknik cakap semuka) and listen to them by taking a note and recording (teknik rekam dan catat) on their responses or their spontaneous stories that are successfully provoked by the researcher. This record is used as a data checker when there is a doubt about the data (which has been recorded). If the required data has been obtained, the next stage is how the data is processed and analyzed. 
The list of questions used in this study is 300 basic vocabulary Swadesh modified according to the needs and objectives of the study. This question list consists of three groups of questions and is divided into 12 parts, namely vocabulary which contains the following meanings: kinship system, pronouns, body parts, parts of the house, tools, conditions and parts of nature, plants and fruit - fruits, animals / animals, food / drinks, properties / circumstances, abstract expressions and verbs, and question words, conjunctions, and others. The vocabulary used is the Sundanese vocabulary everyday.

The analytical method used in this study is the comparative-synchronic method. In other words, the data obtained from the various villages studied are compared with each other and compared to other Sundanese languages.

This research was conducted in Pangandaran Regency, West Java Province, Indonesia, by selecting five districts as observation areas which are determined based on the direction of the wind. In each the district, four villages are also chosen based on the direction of the wind. The areas that are taken as research sites are Cimerak District (Legok Jawa Village, Kertaharja Village, Masawah Village, and Sindangsari Village); Padaherang District (Wuluh Village, Paledah Village, Maruyungsari Village, and Sindangwangi Village); Kalipucang District (Tunggilis Village, Bagolo Village, Cibuluh Village, and Emplak Village); Sidamulih District (Cikembulan Village, Pajaten Village, Sidamulih Village, and Sukaresik Village); and Pangandaran District (Wonoharjo Village, Sidomulyo Village, Sukaharjo Village, and Pananjung Village).

\section{RESULTS AND DISCUSSION}

The geographical position of the Sundanese ethnic community in Pangandaran Regency, West Java, as a native speaker of Sundanese language is very strategic. It is because the speakers of Sundanese language in Pangandaran Regency make it possible to interact with other language speakers, especially Javanese language. Pangandaran Regency area is one of the interprovincial border areas, namely West Java Province and Central Java Province. Each border area is often a transitional language, not only in administrative aspects but also in aspects of language and culture. Mutual influence between languages and intercultural is commonplace in border areas. Pangandaran Regency dialect Sundanese language interacts with Javanese language in Cilacap Regency, Central Java. Javanese language is also widely found in the Pangandaran area.

Traces of the influence of Javanese culture are clearly seen in Pangandaran, such as the names of the places in several Pangandaran area that are identical to the rules of phonology of Javanese language, such as Kedung Wuluh, Tunggilis, Bagolo, Wonoharjo, Sidomulyo, and Sukoharjo. This condition reinforces one thing, that the administrative region cannot limit where a language must be spoken.

Linguistically, even though Javanese language is spoken by a small portion of the community in Pangandaran Regency. However, Sundanese language with Pangandaran dialect is the most potential language to experience the language shifting. Besides the insistence of Indonesian as a national language and English as an international language, Sundanese language Pangandaran dialect also received pressure from Javanese ethnic population which the number was increasingly raised in Pangandaran administrative region. Javanese people experienced a fairly significant demographic increase. This condition is caused by many factors, ranging from economic, social, political and cultural factors.

\subsection{The Characteristics of Javanese Language Migration and its Impact on Sundanese Language Pangandaran Dialect}

Javanese language migration in Pangandaran (West Java - Indonesia) can be seen from the lingual realization and lingual conditions in the region. Although not all areas in Pangandaran are affected by Javanese language, but there are some areas where Javanese language developed in there, such as in Pangandaran District (Wonoharjo Village, Sidomulyo Village, Sukahurip Village, and Pananjung Village); Kalipucang District (Bagolo Village, Emplak Village and Tunggilis Village). The presence of traces of language migration and the influence of Javanese language in Pangandaran can be found, such as from the existence of the same glosses and etymons; glosses with the same realization; and glosses in the same etymon. 
Migration of Javanese Language and its Influence on Sundanese Language Pangandaran Dialect in West Java, Indonesia: A Studi in Geolinguistic

The next question is, does the existence of the same glosses and etymon in a speech area become a marker of language retention or just the opposite? The same glosses and etymon are the markers that the both languages come from the same family, namely the Austronesian language family. In addition, the existence of the same glosses and etymon in a language speech community is still a debate with dualism of opinion. The first opinion states that the existence of the same glosses and etymon in a language speech community is impossible to be used as an indicator of the retention of a language. It is because the similarity of realization can also indicate the weakness of language retention so that the regional language absorbs and interferes with the language that comes, in this case Sundanese language absorbs and interferes with Javanese. The second opinion states that if the conditions of each language interacting are equally strong in giving influence, then the similarity of realization can be understood as the existence of language retention in each language that interacts. In such conditions, speakers of each language compete to influence other languages to maintain their language existence. Until the time later, it is unclear what language affects which language. In the context of language in Pangandaran, it seems that the first opinion is more relevant, considering that in fact Sundanese language is a language that is more influenced by Javanese language as an immigrant language.

The influences of the Javanese language on Sundanese language can be seen in phonological and lexical aspects. The existence of internal innovations in Sundanese language vocabulary influenced by Javanese language through various phoneme correspondences and external innovations through the whole realization of Javanese language vocabulary is one sign of the influence of the Javanese language on Sundanese language.

The more description of the influence of Javanese language on Sundanese language can be seen from the proofs below.

Table1

\begin{tabular}{|c|c|c|c|}
\hline No. & Gloss & Form of Realization & Observation Site \\
\hline 1 & head & $\begin{array}{l}\text { sira } \\
\text { sirah }\end{array}$ & $\begin{array}{l}3,4,5 \\
1,2\end{array}$ \\
\hline 2 & neck & $\begin{array}{l}\text { bö?ö }{ }^{\circ} y \\
\text { böhöy }\end{array}$ & $\begin{array}{l}3,4,5 \\
1,2\end{array}$ \\
\hline 3 & tooth & $\begin{array}{l}\text { huntu? } \\
\text { Untu? }^{?} \\
\text { untu }\end{array}$ & $\begin{array}{l}2 \\
3,4 \\
1,5\end{array}$ \\
\hline 4 & mouth & $\begin{array}{l}\text { biwir } \\
\text { bibir } \\
\text { lambe }\end{array}$ & \\
\hline 5 & liver & $\begin{array}{l}\text { hate } ? \\
\text { ati } \\
\text { ate? }\end{array}$ & $\begin{array}{l}1,2 \\
3 \\
4,5\end{array}$ \\
\hline 6 & bone & $\begin{array}{l}\text { tulang } \\
\text { balung }\end{array}$ & $\begin{array}{l}1,2,3 \\
4,5\end{array}$ \\
\hline 7 & mother & $\begin{array}{l}\text { mama? } \\
\text { piyun } \\
\text { induy }\end{array}$ & $\begin{array}{l}1 \\
4,5 \\
2,3 \\
\end{array}$ \\
\hline 8 & older sister & $\begin{array}{l}\text { ayu } \\
\text { yayu? } \\
\text { teteh }\end{array}$ & $\begin{array}{l}3 \\
4,5 \\
1,2\end{array}$ \\
\hline 9 & water & $\begin{array}{l}\text { banyu? } \\
\text { cai }\end{array}$ & $\begin{array}{l}4,5 \\
1,2,3\end{array}$ \\
\hline 10 & ashes & $\begin{array}{l}\text { ləbu? } \\
\text { abu? } \\
\text { awu }\end{array}$ & $\begin{array}{l}2 \\
1,3 \\
4,5\end{array}$ \\
\hline 11 & fire & $\begin{array}{l}\text { sönö? } \\
\text { gəni }\end{array}$ & $\begin{array}{l}2,3 \\
1,4,5\end{array}$ \\
\hline 12 & star & $\begin{array}{l}\text { bentay } \\
\text { lintay } \\
\text { bintay }\end{array}$ & $\begin{array}{l}2 \\
4,5 \\
1,3 \\
\end{array}$ \\
\hline 13 & moon & bulan & $1,2,3$ \\
\hline
\end{tabular}


Migration of Javanese Language and its Influence on Sundanese Language Pangandaran Dialect in West Java, Indonesia: A Studi in Geolinguistic

\begin{tabular}{|l|l|l|l|}
\hline & & wulan & 4,5 \\
\hline 14 & sand & pasir & 1,2 \\
& & kösik & 3,4 \\
& & wədi & 5 \\
\hline 15 & soil & tanöh & $1,2,3,4$ \\
& & lomah & 5 \\
\hline
\end{tabular}

Notes:

Obervation Site 1 = Cimerak District

Observation Site 2 = Sidamulih District

Observation Site 3 = Kalipucang District

Observation Site 4 = Padaherang District

Observation Site 5 = Pangandaran District

\begin{tabular}{|c|c|c|}
\hline head & : & $\begin{array}{l}\text { sira } \\
\text { sirah }\end{array}$ \\
\hline neck & : & $\begin{array}{l}\text { bö? ön } \\
\text { böhön }\end{array}$ \\
\hline tooth & : & $\begin{array}{l}\text { huntu? } \\
\text { Untu? } \\
\text { Untu }\end{array}$ \\
\hline liver & : & $\begin{array}{l}\text { hat } ? \\
\text { ati } \\
\text { at } \varepsilon ?\end{array}$ \\
\hline crocodile & $:$ & $\begin{array}{l}\text { buhaya } \\
\text { buaya? }\end{array}$ \\
\hline chicken & $:$ & $\begin{array}{l}\text { hayam } \\
\text { ayam }\end{array}$ \\
\hline green & : & $\begin{array}{l}\text { hejo? } \\
\text { cjo? } \\
\text { ijo? }\end{array}$ \\
\hline black & $:$ & $\begin{array}{l}\text { hidön } \\
\text { idöy } \\
\text { irəy }\end{array}$ \\
\hline rain & $:$ & $\begin{array}{l}\text { hujan } \\
\text { ujan } \\
\text { udan }\end{array}$ \\
\hline life & : & $\begin{array}{l}\text { hirup } \\
\text { idup } \\
\text { urip }\end{array}$ \\
\hline wash & : & $\begin{array}{l}\text { nyösöhan } \\
\text { nyösö? }{ }^{2} \text { an }\end{array}$ \\
\hline
\end{tabular}

Besides, the typical of Javanese language migration and its influence on Sundanese language can also be seen from the phonological correspondence, such as correspondence $\varnothing \sim=\mathrm{h} / \#-$ and correspondence $\mathrm{w} \sim=\mathrm{b} / \#-$. Correspondence $\varnothing \sim=\mathrm{h} / \#$ - can be seen from the data below.

Meanwhile correspondence $\mathrm{w} \sim=\mathrm{b} / \#-$ can be seen from the data as written below.

\begin{tabular}{|l|l|l|}
\hline ashes & $:$ & $\begin{array}{l}\text { abu? } \\
\text { ləbu? } \\
\mathrm{awu}^{?}\end{array}$ \\
\hline rock & $:$ & $\begin{array}{l}\text { batu? } \\
\text { watu? }\end{array}$ \\
\hline moon & $:$ & $\begin{array}{l}\text { bulan } \\
\text { wulan }\end{array}$ \\
\hline
\end{tabular}

\subsection{Javanese Language Migration Pattern in Pangandaran (West Java-Indonesia)}

One of the traces of the pattern of Javanese language migration in Pangandaran can be seen, through the calculation of the percentage of Sundanese language influences in each observation area. The 
more vocabulary in an observation area affected by Javanese language - whether through lexical innovation or through phonological internal innovation - means that the area is alleged to have low Sundanese language resistance and is likely to be the starting point for the entry of Javanese language into Sundanese language, and so on. Therefore, let's look at the calculation of the percentage of Javanese language influences on Sundanese language in the following table.

Patriantoro (1999) states that data analysis in dialectology is an analysis of lexical variations at each observation point. The lexical variation itself is understood as a concept of the same meaning but represented in a different form. The overall data is mapped dialectally by 266 . In dialectal analysis, data which are phonological variations are grouped as the same words, while data that is morphologically different or lexically is classified as a different lexicon (Nadra, 1997).

Mapping the entire data is done to determine the state of variation in Sundanese language in Pangandaran and its relationship with Javanese language migration. The results of this mapping are then calculated by the different lexicons in each observation area. This difference in lexicon calculation between points of observation is to determine linguistic distance in the percentage between points of observation.

Of the five observation areas, seven observation sites are determined which with the different lexicon are calculated by forming triangle or facets, namely 1-2, 1-5, 2-3, 2-5, 3-4, 3-5, and 4-5.

\begin{tabular}{|l|l|}
\hline \multicolumn{1}{|c|}{ Line between Observation Areas } & \multicolumn{1}{c|}{ Lexical Variation from Observation Areas } \\
\hline 1 ------------------ 2 & 89 \\
\hline 1 -------------------- 5 & 104 \\
\hline 2 ------------------- 3 & 79 \\
\hline 2 ---------------- 5 & 82 \\
\hline 3 ----------------- 4 & 48 \\
\hline 3 ----------------- 5 & 41 \\
\hline 4 ------------------- 5 & 43 \\
\hline
\end{tabular}

Furthermore, lexical difference from observation areas are calculated to gain the percentage of lexical difference which aims to know the language criteria. The calculation is carried out by using dialectometry formula as written below.

$$
\frac{\mathrm{sXd} \%}{\mathrm{n}}=\mathrm{d} \%
$$

s: number of lexical differences from observation areas

$\mathrm{n}$ : total number of glosses that are compared

$\mathrm{d} \%$ : total percentage of variation

Based on the formula, it is measured the lexical variation or differentiation as the following criteria:

$81 \%$ ke atas: lexical variation is considered as language variant

$51 \%-80 \%$ : lexical variation is considered as dialect variant

$31 \%-50 \%$ : lexical variation is considered as sub dialect variant

21\%-30\%: considered as accent variant

$20 \%$ ke bawah: is considered as no variant

From the above calculation of the linguistic criteria by using dialectometry formula, the results are described as follows.

\begin{tabular}{|c|c|}
\hline Line between Observation Areas & Lexical Variation from Observation Areas \\
\hline 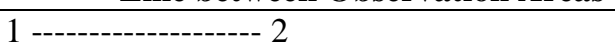 & $33,4 \%$ \\
\hline 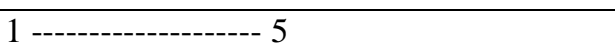 & $39,1 \%$ \\
\hline 2 --------------------- 3 & $29,7 \%$ \\
\hline 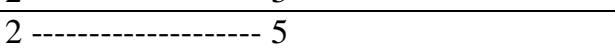 & $30,8 \%$ \\
\hline 3 --------------------- 4 & $18 \%$ \\
\hline 3 -------------------- 5 & $15,4 \%$ \\
\hline 4 -------------------- 5 & $16,2 \%$ \\
\hline
\end{tabular}


Based on the dialectometry calculation above by using the triangle between observation areas, the highest linguistic variation obtained is at observation site $1-5$, while the lowest linguistic variation is at observation site 3-5. The following is the percentage of linguistic elements from the observation areas which with using inter-village triangles.

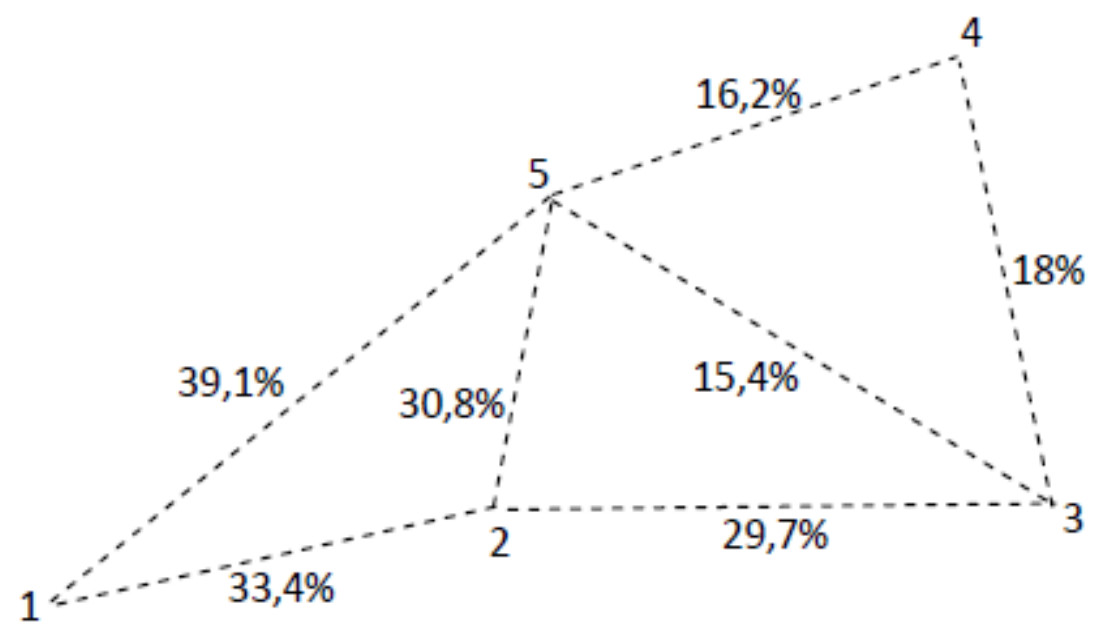

Map1: The Percentage of Linguistic Elements from The Observation Areas Using Inter-Village Triangles

Furthermore, to find out the Javanese language migration pattern in Pangandaran, we can relate it to the pattern of language distribution. There are several theories that can be used, including: wave theory and tree theory. Wave theory is likened to an object falling in the middle of a pond. Exactly the point where objects fall has the biggest wave; some distance from the point where objects fall has increasingly smaller wave ripples; until far from the point where objects fall, the wave ripples are getting weaker; and the farther the ripples the more it no longer appears. As for the tree theory in the spread of a language, the mother language develop into several language variations due to differences in speaker locations, each language variation develop again into a variety of languages because the speakers' geographical locations are farther away, and each language variation develop into several new language variations because of the differences in geography, and so on. In this case, this research adopts the wave theory to assess the distribution of the influence o Javanese language in Pangandaran. This theory is very relevant to the linguistic conditions that exist in the region.

Overall, from the five observation areas, the influence of Javanese language has different percentages in each observation area. Qualitatively, the order of influence of Javanese language on the Sundanese dialect of Pangandaran is at observation site 5 (Pangandaran District), observation site 4 (Padaherang District), and observation site 3 (Kalipucang District). Observation site 1 and 2 are relatively not too high in percentage of the influence of Javanese language on the Sundanese language dialect Pangandaran. Observation site 3 and 4 are geographically adjacent and bordering to Cilacap Regency area in Central Java, so it is natural that in these two observation areas there are influences of Javanese culture elements on the Sundanese language dialect Pangandaran. What is interesting here is observation site 5 which is geographically located in the middle of Pangandaran Regency and is not directly adjacent to Cilacap Regency area, but the influence of the Javanese language in this observation area is the highest. That means, there are other factors besides geographical factors which make the influence of Javanese language on Sundanese dialect Pangandaran very high.

From the lingual reality in Pangandaran, it is associated with the theory of the language distribution, that the influence of Javanese language on Sundanese dialect Pangandaran is spread in waves. Furthermore, if we relate to the theory of geographical distribution, there are two patterns of the distribution, namely centrifuges (away from the center) and centripetal (approaching the center). In other words, the pattern of Javanese language migration - more precisely the pattern of the influence of elements of Javanese language - on Sundanese dialect of Pangandaran is spread through the wave theory with a wave centrifugal pattern (away from the center). Observation site 5 (District) which has the highest level of Javanese language influence becomes the center of the wave, and the other 
observation sites become peripheral area. If depicted, the Javanese language migration pattern in Pangandaran can be pictured as below.

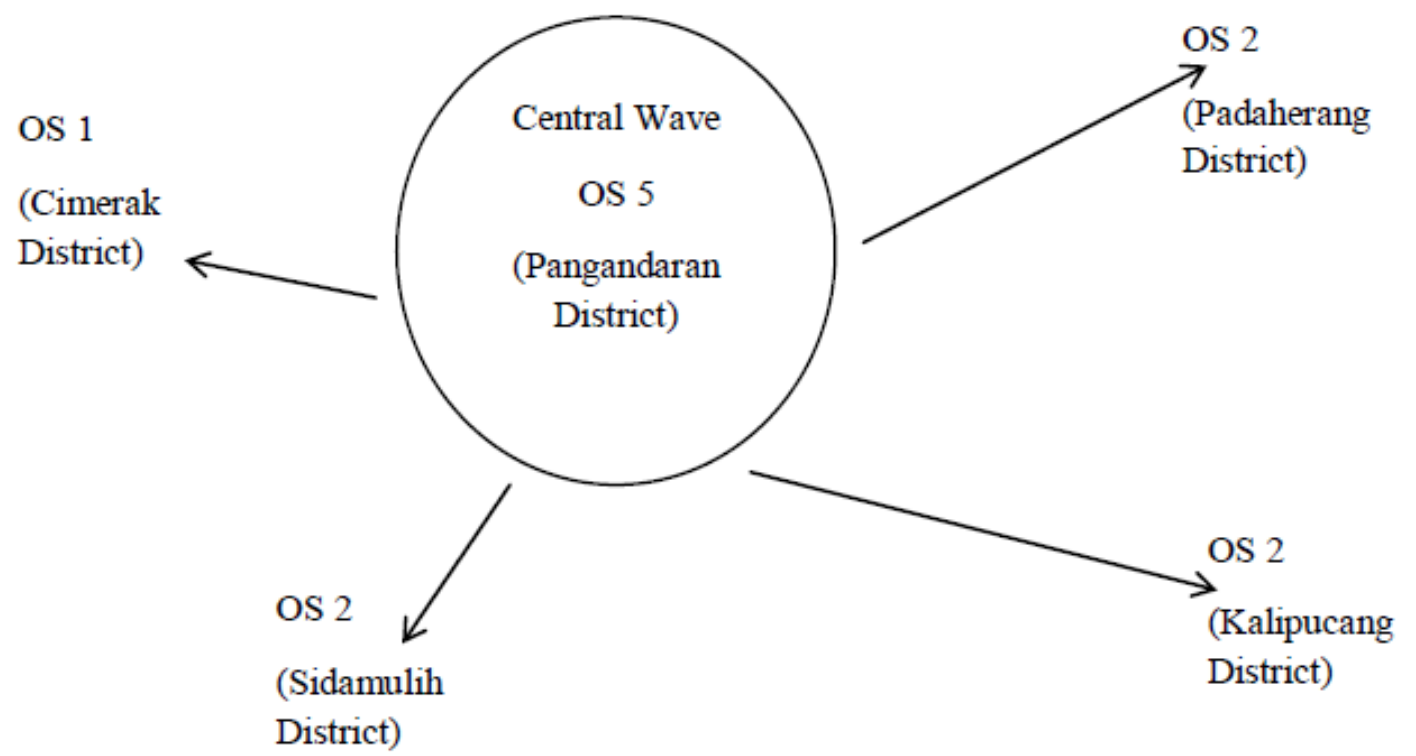

Picture1: Distribution Pattern of the Influence of Javanese Language on Sundanese Language Dialect Pangandaran (West Java - Indonesia)

Notes: OS: Obeservation Site

\subsection{Determinants of Javanese Language Migration and Its Influence on Sundanese Language Dialect Pangandaran (West Java - Indonesia)}

There are several determinants of the existence of Javanese migration which influence Sundanese language dialect Pangandaran (West Java - Indonesia). These factors are described as follows.

\subsubsection{Historical Factor}

If drawn back in the historical context, the combination of Sundanese and Javanese ethnic in Pangandaran (West Java - Indonesia) has a long historical footprint. In the past, the Sundanese kingdom was born and developed in the area of West Java, and experienced rapid development around the year 669-1579 AD. The center of royal glory occurred when the sultan of Mataram Kingdom under the leadership of Sultan Agung Kusumo Hanyokro (1613-145). At that time, almost all Central Java area and parts of East Java area were under his leadership. In the context of Pangandaran locality, it turns out that although the areas of Central Java and East Java had been widely conquered, it did not lead the Javanese people to migrate to West Java, in this case is Pangandaran. There are no studies that can provide an overview of the migration of Javanese to Pangandaran before the 20th century.

The description of the Javanese ethnich migration to Pangandaran (West Java - Indonesia) appears in the fochlor script that developed in the Javanese ethnic group in Pangandaran. In the fochlor, it is stated that there is a Javanese who is considered a powerful man who build Pangandaran area which at that time was still a wilderness. His name is Mbah Bungkus. In the fochlor, it was told that the Regent of Sukapura at that time asked for help to his people to open the forest in the area which would become a habitable area. However, no one was able to fulfill the request of the regent. Until finally the regents in the Java region asked Mbah Bungkus for help. With his supernatural powers, Mbah Bungkus successfully opened the Cikembulan area - the forerunner of the Pangandaran region. Etymologically, Cikembulan comes from the word kembulan which means to unite or gather. That means, Cikembulan is considered as a union or association between ethnic Javanese and ethnic Sundanese, and they live side by side.

According to the fochlor, the name of Pangandaran was born to a Sundanese person who at that time was carrying food for Javanese people who were farming. The food is called pangan by the Javanese people while the Sundanese people call the food by daharan. The combination of the two words 
finally resulted the word pangandaharan which later changed to pangandaran (Samino, Interview April 21, 2019).

Historically, the birth of Pangandaran did have cultural complexity. The close relationship between ethnic Sundanese and ethnic Javanese makes Pangandaran one of the multiethnic, multicultural and multilingual regions. On that basis, it is understood that linguistic conditions in the Pangandaran area are so complex.

\subsubsection{Geographical and Demographic Factors}

Other factors that influence the Javanese language migration in Pangandaran (West Java - Indonesia) can be seen from the geographical and demographic aspects. From a geographical point of view, Pangandaran is considered to be a region that has natural attraction, soil fertility, availability of jobs, and residents' culture which open to other ethnicities that have attracted people from outside the region to migrate to Pangandaran (West Java - Indonesia). This geographical factor, according to our informant, Samino (the second generation of immigrants from Java), was one of the factors triggering the migration of ethnic Javanese to Pangandaran. This geographical factor cannot be separated from demographic factors, the abundance of Pangandaran's natural wealth has caused a surge in migration of ethnic Javanese to the Pangandaran area. This ethnic Javanese migration carries cultural influences, including the influence of the Javanese language on the Sundanese dialect Pangandaran.

\subsubsection{Political Factor}

Talking about transmigration in Indonesia, certainly very closely related to the figure of the second president of Republic Indonesia, namely Suharto. During the New Order era, transmigration became one of Soeharto's mains programs contained in the 'Five-Year Development' Pembangunan Lima Tahun (Pelita) 1 to 6. The Soeharto era transmigration program was included in the new order transmigration generation. Previously, in 1905, d. 1942 known as colonization. Then Japan entered Indonesia, then the term changed to rodi work (romusha). Post-independence until 1966, in the old order period, then there was transmigration, but the continuity did not go smoothly. When Suharto became president of the Republic of Indonesia, Pelita I to VI was launched in 1969, and at that time transmigration began to be intensified.

The transmigration program in Soeharto era is often known as bedol desa or a sejuta gambut. This political policy in turn has an impact on the socio-cultural life in the midst of Indonesian society. Many of the vacant land that is worked on by immigrants and then these lands, along with the times and generations, turned into habitable areas starting from the village, village, to district levels.

Pangandaran Regency (West Java - Indonesia) - which previously entered into the administrative area of Ciamis Regency - was also inseparable from Suharto's political policies. In this region, at that time, there were still lots of vacant land that had to be cultivated. Until finally many people from Javanese ethnic groups moved to parts of Pangandaran and settled until the present generation. This political policy also has an impact on the socio-cultural dynamics in Pangandaran, especially in the lingual aspects of the region.

\section{CONCLUSION}

The geographical position of the Sundanese ethnic community in Pangandaran Regency, West Java as a native speaker of Sundanese language is very strategic. Because they are in a language enclave, speakers of Sundanese language in Pangandaran make it possible to interact with other language speakers, especially Javanese language. Pangandaran area is one of the interprovincial border areas, namely West Java Province and Central Java Province.

Traces of the influence of Javanese culture are clearly seen in Pangandaran. One of them can be seen from the names of the places in Pangandaran area that are identical to the rules of phonology of Javanese language, such as Kedung Wuluh, Tunggilis, Bagolo, Wonoharjo, Sidomulyo, and Sukoharjo. This condition reinforces one thing, that the administrative region cannot limit where a language must be spoken.

Migrasi bahasa Jawa yang ada di Pangandaran bisa terlihat dari realisasi lingual dan kondisi lingual yang ada di wilayah tersebut. Meskipun tidak seluruh wilayah di Pangandaran terpengaruh oleh 
bahasa Jawa, tetapi terdapat beberapa daerah yang menjadi kantong-kantong perkembangan bahasa Jawa di Pangandaran, seperti di Kecamatan Pangandaran (Desa Wonoharjo, Desa Sidomulyo, Desa Sukahurip, dan Desa Pananjung); Kecamatan Kalipucang (Desa Bagolo, Desa Emplak, dan Desa Tunggilis).

Javanese language migration in Pangandaran can be seen from the lingual realization and lingual conditions found in there. Although not all regions in Pangandaran are affected by Javane language, there are some areas which become the area where the Javanese language developed in Pangandaran, such as in Pangandaran District (Wonoharjo Village, Sidomulyo Village, Sukahurip Village and Pananjung Village); Kalipucang District (Bagolo Village, Emplak Village and Tunggilis Village).

The presence of traces of language migration and the influence of the Javanese language in Pangandaran can be seen, some of which, from the existence of the same glosses and etymones; glosses with the same realization; and glosses in the same etymon.

The influences of the Javanese language on Sundanese language can be seen in phonological and lexical aspects. The existence of internal innovations in Sundanese language vocabulary is influenced by Javanese language through various phoneme correspondences and external innovations through the realization of Javanese language vocabulary as a whole is one sign of the influence of the Javanese language on Sundanese language.

The pattern of Javanese language migration in Pangandaran can be seen, one of which, through the calculation of the percentage of Sundanese language influences in each observation area. Overall, from the five observation sites, the influence of the Javanese language has different percentages in each observation area. Qualitatively, the order of influence of the Javanese language on the Sundanese language dialect of Pangandaran is found in the observation site 5 (Pangandaran District), observation site 4 (Padaherang District), and observation site 3 (Kalipucang District). The observation site 1 and 2 are relatively not too high in the influence of the Javanese language on the Sundanese language dialect Pangandaran.

The pattern of Javanese language migration - more precisely the pattern of distribution of the influence of Javanese language elements - on Sundanese language Pangandaran dialect is spread through wave theory with a centrifugal pattern (away from the center) wave.

Terdapat beberapa faktor penentu adanya migrasi bahasa Jawa yang berpengaruh terhadap bahasa Sunda dialek Pangandaran, yaitu faktor historis, faktor geografis-demografis, dan faktor politis.

There are several determinants of the Javanese language migration that influence Sundanese language dialect Pangandaran, namely historical factors, geographical-demographic factors, and political factors.

\section{REFERENCES}

[1] Ayatrohedi. (2002). Pedoman Penelitian Dialektologi. Jakarta: Pusat Bahasa Departemen Pendidikan Nasional.

[2] Blust, Robert. (1977). The Proto Austronesian Pronouns and Austronesian Subgrouping. Leiden: A Preliminary Report, Rijkuniversiteit.

[3] Djojosuroto, K. dan M.L.A. Sumaryati. (2004). Prinsip-Prinsip Dasar Pedalam Penelitian Bahasa dan Sastra. Bandung: Nuansa.

[4] Dyen, Isodora. (1965). "Lexicostatistical Classification of The Austronesia Language". Memory of the International Journal of American Linguistics, 28: 31-42.

[5] Mahsun. (1995). Dialektologi Diakronis Sebuah Pengantar. Cet. I. Yoyakarta: Gadjah Mada University Press.

[6] Mbete, Aron Meko. (2003). "Bahasa dan Budaya Lokal Minorita, Asal-Muasal, Ancaman Kepunahan dan Ancangan Pemberdayaan dalam Kerangka Pola Ilmiah Pokok Kebudayaan Universitas Udayana”. Pidato Pengukuhan Jabatan Guru Besar Tetap dalam Bidang Linguistik pada Fakultas Sastra Universitas Udayana, 25 Oktober 2003.

[7] Mees, CA. (1967). Perbandingan Bahasa-Bahasa Nusantara. Kualalumpur: University of Malaya Press.

[8] Mulyana, Slamet. (1975). Asal Bangsa dan Bahasa Nusantara. Jakarta: Balai Pustaka. 
Migration of Javanese Language and its Influence on Sundanese Language Pangandaran Dialect in West Java, Indonesia: A Studi in Geolinguistic

[9] Nadra. (1997). Geografi Dialek Bahasa Minangkabau. Disertasi Doktor Universitas Gadjah Mada, Yogyakarta

[10] Patriantoro. (1999). Dialektologi Bahasa Melayu Di Kalimanan Barat. FKIP Uiversitas Tanjungpura Pontianak.

[11] Sudaryanto. (2015). Metode dan Teknik Analisis Bahasa: Pengantar Penelitian Wahana Kebudayaan Secara Linguistis. Yogyakarta: Penerbit Universitas Sanata Dharma.

[12] Suryata, Pujiati. (1998). "Subgrouping dan Migrasi Sembilan Bahasa di Indonesia: Kajian Linguistik Komparatif”. Jurnal Iptek dan Humaniora, Nomor 3 tahun ke-3, 111-125.

[13] Wahyuni, Sri. (2010). "Tarik-Menarik Bahasa Jawa Dialek Banyumas dan Bahasa Sunda di Perbatasan Jawa Tengah-Jawa Barat Bagian Selatan sebagai Sikap Pemertahanan Bahasa oleh Penutur”. Magister Linguistik PPS Undip Semarang. 6 Mei 2010.

[14] Wijana, I Dewa Putu. (2006). Sosiolinguistik: Kajian Teori dan Analisis. Yogyakarta: Pustaka Pelajar.

\section{AUTHORS' BIOGRAPHY}

Wagiati, Faculty of Cultural Sciences, Universitas Padjadjaran, Bandung - Sumedang KM 21, Jatinangor, Sumedang, Indonesia

Nani Darmayanti, Faculty of Cultural Sciences, Universitas Padjadjaran, Bandung - Sumedang KM 21, Jatinangor, Sumedang, Indonesia

Duddy Zein, Faculty of Communication Sciences, Universitas Padjadjaran, Bandung - Sumedang KM 21, Jatinangor, Sumedang, Indonesia

Citation: Wagiati, Nani Darmayanti, Duddy Zein. "Migration of Javanese Language and its Influence on Sundanese Language Pangandaran Dialect in West Java, Indonesia: A Studi in Geolinguistic". International Journal of Humanities Social Sciences and Education (IJHSSE), vol. 6, no.7, 2019, pp. 22-33. doi: http://dx.doi.org/ 10.20431/2349-0381.0607004.

Copyright: (C) 2019 Authors. This is an open-access article distributed under the terms of the Creative Commons Attribution License, which permits unrestricted use, distribution, and reproduction in any medium, provided the original author and source are credited. 